\title{
HISTORY OF PHYSIOLOGICAL SCIENCES
}

\author{
ALEXANDER v. KORÁNYI \\ who first coined the term \\ "Renal Insufficiency" \\ and characterized it functionally
}

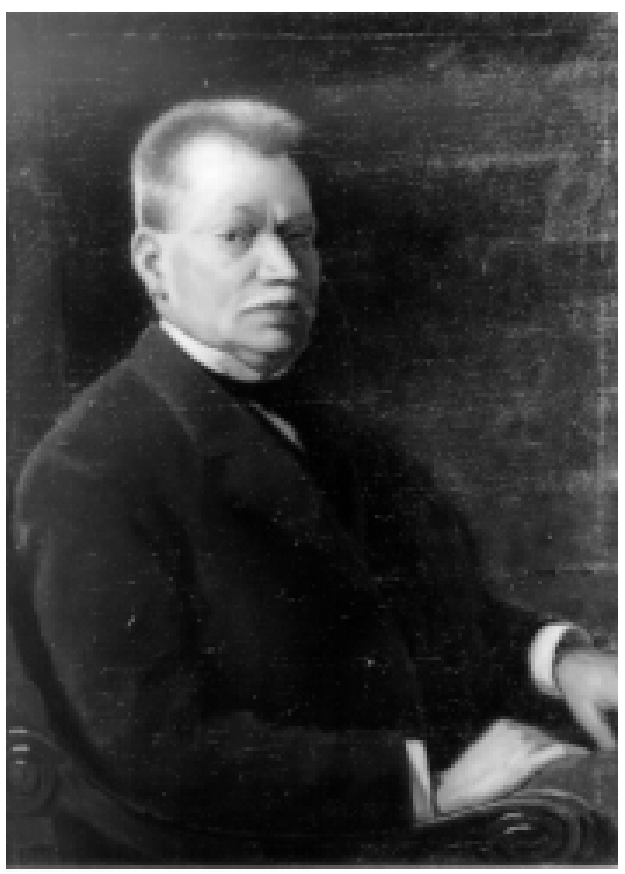

Alexander v. Korányi (1866-1944) was born in Budapest. He graduated in medicine in Budapest, then he moved to Strassbourg for his fellowship with F. Hoppe Seiler. He devoted himself to the application of a physicochemical approach in the study of renal function in health and disease.

Claude Bernard has postulated that healthy human organism is characterized by stable osmotic concentration of "milieu intérieur". Korányi assumed that kidneys regulate the osmolality of urine in such a way that the osmolality of blood should remain constant, concluding that the kidneys control the milieu interieur (1894). 
He employed the measurement of freezing point depression (FDP) to follow the osmolality of urine and blood in many different conditions in order to better understand the kidney function under normal and pathophysiological states [1]. He recognized the marked reserved capacity of the kidneys to change the osmolality of urine. In a patient with a one-side ureterostomy he demonstrated that FDP of urine from the diseased kidney changed less than that in the contralatoral healthy kidney. He concluded that the urine FDP is dependent on the state of kidney function and not on a systemic metabolic change. He also postulated, based on his measurements, that the difference between the achievable minimal and maximal FDP, decreases proportionally to the severity of the kidney disease. He recognized that the maximum FDP decreases while the minimum FDP increases by the progression of the renal disease and finally both values get close to the FDP value of blood. To describe this process he first coined the terms "hyposthenuria" and "isosthenuria". In his opinion, since less molecules were found in the urine of a diseased kidney, the retention of molecules caused the characteristic symptoms of renal failure (1896). Thus renal failure as a functional term was established by v. Korányi as it was emphasized also by Volhard (1938 Buenos Aires). $\mathrm{He}$ also observed and recognized the hyposthenuric compensatory polyuria. He pinpointed the general malpractice of that time which was the withdrawal of fluid intake under this condition. Based on the results of his functional studies, v. Korányi adjusted the patient's diet and life style to the remaining functional capacity of the kidney $[2,3,4]$.

He stated: "If we were be able to control the diet of kidney diseased patients in such a way that the number of molecules produced by the metabolism would not exceed the remaining molecular excretion capacity of the kidney then we would do a world of benefit for the patients."

Alexander v. Korányi was nominated for Nobel prize for his renal research as documented in the publication produced by the Nobel Institute [5]. An inscript of the publication reads as:

“...In his studies of the functions of the kidneys, A. v. KORÁNYI employed at an early date physicochemical methods. He found that while the variations in the lowering of the freezing point of blood are extremely small, they are usually considerable in the case of urine, owing the differences in its solid contents. In the case of certain kidney diseases, v. KORÁNYI noticed that the variations had become smaller and utilized the reduction in the range of toleration to measure the extent of the defects in the kidneys. While these were an important step in the application to medicine of the advances made in physical chemistry, they were not held to merit a Nobel Price."

Korányi's accomplishments in nephrology might not have been enough to have recognized him as a Nobel prize laureate, yet it is certainly enough to appreciate him as the one whose works created a milestone in the development of nephrology. 


\section{REFERENCES}

1. Korányi, A. v.: Physiologisch-klinische Untersuchungen über den osmotischen Druck in der tierischen Flüssigkeiten. Zeitsch f Klin Medizin, 33, 1-55 (1897).

2. Korányi, A. v.: Über den Harn und das Blut bei Nierenkrankheiten. Zeitsch f Klin Medizin, 34, 1-52 (1898).

3. Korányi, A. v.: Physikalisch-chemische Methoden und Gesichtspunkte in ihrer Anwendung auf die pathologische Physiologie der Nieren, in Physikalische Chemie und Medizin, ed. Korányi, A. v., Richter, P. F., Leipzig, G. Thieme, 1907, pp. 133-190.

4. Korányi, A. v.: Vorlesungen über funktionelle Pathologie und Therapie der Nierenkrankheiten. Berlin, Springer, 1929.

5. Liljestrang, G.: "The Price in Physiology or Medicine" in Nobel the man and his Prices, edited by Nobel Foundation, Amsterdam - London - New York, 1962.

\section{Rosivall}

Correspondence should be addressed to László Rosivall MD, PhD, DSc Med Nephrology Research and Training Center Department of Pathophysiology Faculty of Medicine

Semmelweis University, Budapest H-1089 Budapest, Nagyvárad tér 4, Hungary Phone: 36-1-210-2956, 36-1-2100-100

Fax: 36-1-2100-100

Email: rosivall@net.sote.hu 